\title{
GAMBARAN KEPERCAYAAN DAN TRADISI IBU HAMIL DALAM ASUHAN KEHAMILAN DI WILAYAH DESA CIKUNIR KABUPATEN TASIKMALAYA TAHUN 2018
}

\author{
OLEH : \\ Chanty Yunie Hartiningrum, S.SiT, M.Kes \\ Annisa Rahmidini, SST., M.Keb \\ (chanty.yunie@gmail.com)
}

\section{A. ABSTRAK}

Kehamilan merupakan suatu keadaan dimana seorang wanita yang didalam rahimnya terdapat embrio atau fetus. Kehamilan dimulai pada saat masa konsepsi hingga lahirnya janin, dan lamanya kehamilan dimulai dari ovulasi hingga partus yang diperkirakan sekitar 40 minggu dan tidak melebihi 43 minggu (Kuswanti, 2014). Hal ini seperti yang dijelaskan oleh O’Neil (2006) bahwa semua budaya yang diwariskan cenderung untuk berubah tetapi ada kalanya juga dipertahankan. Ada proses dinamis yang mendukung diterimanya hal-hal dan ide-ide baru dan ada juga yang mendukung untuk mempertahankan kestabilan budaya yang ada. Hiller (2003) menyatakan bahwa ketika perubahan terjadi, maka terjadi destruksi nilainilai tradisional, kepercayaan, peran dan tanggungjawab, pendidikan, keluarga dan lain-lain yang hampir simultan dengan proses konstruksi cara baru sebagai pengaruh dari perubahan sosial. Tujuan dari penelitian ini adalah untuk mengetahui Gambaran Kepercayaan Dan Tradisi Budaya Pada Masa Kehamilan Di Wilayah Desa Cikunir Kabupaten Tasikmalaya Tahun 2018.

Jenis penelitian yang digunakan adalah kuantitatif dengan metode deskriptif. Populasi dan sampel penelitian ini adalah ibu hamil trimester I - III yang berada di Wilayah Desa cikunir yang berjumlah 41 orang. Teknik pengambilan sample adalah total sampel dimana seluruh sasaran di jadikan sampel dalam penelitian ini. Instrumen peneliti yang digugunakan kuesioner yang mengukur gambran kepercayaan dan tradisi ibu hamil dalam asuhan kehamilan. Analisi data dilakukan dengan cara univariat yang disajikan dalam bentuk table distribusi frekuensi dan di jelaskan secara narasi.

Hasil penelitian diperoleh bahwa masyarakat yang melaksanakan Budaya/Tradisi Syukuran Empat Bulanan dan Tujuh Bulanan yaitu 32 orang (78.0\%), Ibu hamil memiliki pantangan/larang yang harus diikuti ibu hamil pada saat hamil yaitu Tidak setuju 35 orang (85.4\%), Ibu hamil Jangan makan di piring besar yaitu sebanyak setuju 27 orang (65.9\%), Ibu hamil jangan makan pisang dari pohon tumbang yaiyu sebanyak setuju 24 orang ( 58.5\%), Ibu hamil jangan Minm Air ES yaitu sebanyak setuju 25 orang (61.0\%), Ibu hamil memakan makanan pedas menyebabkan bayi lahir sakit yaitu sebanyak setuju 25 orang (61.0\%), Ibu hamil tidak boleh makan nanas, dure, dan tape yaitu sebanyak setuju 21 orang (51.2\%), Ibu hamil sering minum air kelapa muda yaitu setuju 25 orang (61.0\%), Ibu hamil sering minum minyak kelapa yaitu setuju 27 orang (65.9\%), Ibu hamil yang minum madu dan kocokan telur ayam yaitu setuju 27 orang (65.9\%).

Simpulan dari penelitian ini adalah Agar ibu hamil lebih meningkatkan kunjungan kehamilan ke tenaga kesehatan dan meningkatkan upaya pencairan informasi kesehatan melalui kegiatan kelas ibu hamil seperti pelatihan,

penyuluhan.

\section{KataKunci : Kepercayaa, Tradisi, Ibu hamil}




\section{B. PENDAHULUAN}

Kehamilan merupakan suatu keadaan dimana seorang wanita yang didalam rahimnya terdapat embrio atau fetus. Kehamilan dimulai pada saat masa konsepsi hingga lahirnya janin, dan lamanya kehamilan dimulai dari ovulasi hingga partus yang diperkirakan sekitar 40 minggu dan tidak melebihi 43 minggu (Kuswanti, 2014). Jumlah ibu hamil di Indonesia pada tahun 2017 tercatat sekitar 5.324.562 jiwa. Sedangkan di Jawa Tengah, jumlah ibu hamil mencapai 590.984 jiwa (Kemenkes RI, 2018).

Kondisi kesehatan calon ibu pada masa awal kehamilan akan mempengaruhi tingkat keberhasilan kehamilan serta kondisi status kesehatan calon bayi yang masih didalam rahim maupun yang sudah lahir, sehingga disarankan agar calon ibu dapat menjaga perilaku hidup sehat dan menghindari faktor-faktor yang dapat mempengaruhi kondisi calon ibu pada masa kehamilan (Johnson, 2016).

Sosial budaya dapat dilihat sebagai pola dalam suatu wilayah lokal, seringkali dipandang secara birokratis dan sesuatu yang terorganisir, berkembang, berbudaya termasuk teori pemikiran sistem kepercayaan dan aktivitas sehari-hari, hal ini dapat diterapkan dalam praktek keseharian. Terkadang sosial budaya digambarkan menjadi suatu yang tidak dapat ditangkap oleh akal sehat atau sesuatu diluar kemampuan panca indra (Cicourel, 2013).

Kebudayaan memiliki unsur yang sama dalam setiap kebudayaan di dunia. Baik kebudayaan kecil bersahaja dan terisolasi maupun yang besar, kompleks dan dengan jaringan hubungan yang luas. Kebudayaan sangat mudah berganti dan dipengaruhi oleh kebudayaan lain, sehingga akan menimbulkan berbagai masalah yang besar. Dalam suatu kebudayaan terdapat sifat sosialis masyarakat yang didalamnya terdapat suatu ikatan sosial tertentu yang akan menciptakan kehidupan bersama (Sulismadi \& Sofwani, 2011). Kebudayaan mencakup suatu pemahaman komprehensif yang sekaligus bisa diuraikan dan dilihat beragam vairabel dan cara memahaminya. Kebudayaan dalam arti suatu pandangan yang menyeluruh yang menyangkut pandangan hidup, sikap dan nilai. Pembangunan kebudayaan dikaitkan dengan upaya memperbaiki kemampuan untuk recovery, bangkit dari kondisi yang buruk, bangkit untuk memperbaiki kehidupan bersama, bangkit untuk menjalin kesejahteraan. Dalam hal inilah sosial budaya berperan untuk 3 memberikan solusi terbaik bagi beragam bidang kehidupan (Widianto \& Pirous, 2009).

Budaya pada masa kehamilan dan persalinan di sebagian daerah telah terjadi pergeseran namun di sebagian lain masih dipertahankan. Hal ini seperti yang dijelaskan oleh O'Neil (2006) bahwa semua budaya yang diwariskan cenderung untuk berubah tetapi ada kalanya juga dipertahankan. Ada proses dinamis yang mendukung diterimanya hal-hal dan ide-ide baru dan ada juga yang mendukung untuk mempertahankan kestabilan budaya yang ada. Hiller (2003) menyatakan bahwa ketika perubahan terjadi, maka terjadi destruksi nilainilai tradisional, kepercayaan, peran dan tanggungjawab, pendidikan, keluarga dan lain-lain yang hampir simultan dengan proses konstruksi cara baru sebagai pengaruh dari perubahan sosial. Nilai dan ritual yang baru ini menggantikan nilai dan ritual yang lama. Namun di sebagian masyarakat adakalanya terjadi kompromi yang mana nilai dan ritual baru dijalankan dengan tanpa menghilangkan nilai dan ritual lama. 
Berdasarkan studi pendahuluan melalui wawancara singkat yang dilakukan di Di Wilayah Desa Cikunir Kabupaten Tasikmalaya terdapat ibu hamil yang memiliki kepercayaan-kepercayaan tentang acara makanan dan kebiasaan makan yang sudah turun-temurun dilakukan seperti contoh larangan untuk makan dipiring besar, makanan pedas, nanas, duren, tape dan yang lainya dengan alasan akan membahayakan kesehatan bayi.

Berdasarkan uraian tersebut, penulis bermaksud melakukan penelitian mengenai "Gambaran Kepercayaan Dan Tradisi Budaya Pada Masa Kehamilan Di Wilayah Desa Cikunir Kabupaten Tasikmalaya Tahun 2018.

\section{METODOLOGI PENELITIAN}

Jenis penelitian yang digunakan adalah kuantitatif dengan metode deskriptif. Populasi dan sampel penelitian ini adalah ibu hamil trimester I - III yang berada di Wilayah Desa cikunir yang berjumlah 41 orang. Teknik pengambilan sample adalah total sampel dimana seluruh sasaran di jadikan sampel dalam penelitian ini. Instrumen peneliti yang digugunakan kuesioner yang mengukur gambran kepercayaan dan tradisi ibu hamil dalam asuhan kehamilan. Analisi data dilakukan dengan cara univariat yang disajikan dalam bentuk table distribusi frekuensi dan di jelaskan secara narasi. Teknik pengambilan data dilakukan secara langsung dengan sasaran. Waktu pelaksanaan pengambilan data dari tanggal 10 - 20 September 2018.

Analisis data di lakukan dengan cara univariat yang disajikan dalam bentuk tabel distribusi dan dijelaskan secara narasi.

\section{HASIL PENELITIAN}

Kriteria Responden

Karakteristik ibu hamil berdasarkan umur di Wilayah Desa Cikunir Kabupaten Tasikmalaya Tahun 2018

\begin{tabular}{|c|c|c|}
\hline Umur & Jumlah & $\%$ \\
\hline $\begin{array}{l}\text { Resiko } \\
\text { Tahun) }\end{array}$ & $(<20$ Tahun, $>3510$ & 24.4 \\
\hline $\begin{array}{l}\text { Tidak } \\
\text { Tahun) }\end{array}$ & Beresiko $\quad(20-3531$ & 75.6 \\
\hline Total & 41 & 100.0 \\
\hline
\end{tabular}

Berdasarkan tabel 5.1 Karaketristik ibu hamil berdasarkan umur di Wilayah Desa Cikunir Kabupaten Tasikmalaya Tahun 2018 sebagian besar termasuk kelompok umur tidak beresiko atau berkisar antara 20-35 tahun yaitu sebanyak 31 orang $(75.6 \%)$.

Karakteristik ibu hamil berdasarkan pekerjaan di Wilayah Desa Cikunir Kabupaten Tasikmalaya Tahun 2018

\begin{tabular}{|c|c|c|}
\hline Pekerjaan & Jumlah & Persentase \\
\hline $\begin{array}{ll}\text { Ibu } & \text { Rumah } \\
\text { Tangga } & \\
\end{array}$ & 33 & 80.5 \\
\hline Buruh & 7 & 17.1 \\
\hline Pegawai swasta & 1 & 2.4 \\
\hline Total & 41 & 100.0 \\
\hline
\end{tabular}

Berdasarkan tabel 5.2 Pekerjaan yang dilakukan ibu hamil di Wilayah Desa Cikunir Kabupaten Tasikmalaya Tahun 2018 adalah sebagai ibu rumah tangga yaitu sebanyak 33 orang $(80.5 \%)$. 
Karakteristik ibu hamil berdasarkan Pendidikan di Wilayah Desa Cikunir Kabupaten Tasikmalaya Tahun 2018

\begin{tabular}{|c|c|c|c|}
\hline Pendidikan & & Jumlah & Persentase \\
\hline Tidak Tamat & SD & 7 & 17.1 \\
\hline $\begin{array}{l}\text { Pendidikan } \\
\text { (SD) }\end{array}$ & Dasar & 28 & 68.3 \\
\hline $\begin{array}{l}\text { Pendidikan } \\
\text { Menengah } \\
\text { SMA) } \\
\end{array}$ & (SMP, & 5 & 12.2 \\
\hline $\begin{array}{l}\text { Perguruan } \\
(\mathrm{PT})\end{array}$ & Tinggi & 1 & 2.4 \\
\hline Total & & 41 & 100.0 \\
\hline
\end{tabular}

Berdasarkan tabel 5.3 Karakteristik ibu hamil berdasarkan pendidikan di Wilayah Desa Cikunir Kabupaten Tasikmalaya Tahun 2018 sebagian besar termasuk berpendidikan dasar (lulusan dari SD) yaitu sebanyak 28 orang $(68.3 \%)$.

Karakteristik ibu hamil berdasarkan paritas di Wilayah Desa Cikunir Kabupaten Tasikmalaya Tahun 2018

\begin{tabular}{lll}
\hline Paritas & Jumlah & Persentase \\
\hline Primigravida & 11 & 26.8 \\
\hline Multigravida & 23 & 56.1 \\
\hline Grandegravida & 7 & 17.1 \\
\hline Total & 41 & 100.0 \\
\hline
\end{tabular}

Berdasarkan tabel 5.4 Karakteristik ibu hamil berdasarkan paritas di Wilayah Desa Cikunir Kabupaten Tasikmalaya Tahun 2018 sebagian besar termasuk multigravida yaitu sebanyak 23 orang $(56.1 \%)$.
Karakteristik ibu hamil berdasarkan usia kehamilan di Wilayah Desa Cikunir Kabupaten Tasikmalaya Tahun 2018

\begin{tabular}{lll}
\hline Usia kehamilan & Jumlah & Persentase \\
\hline Trimester 1 & 9 & 22.0 \\
\hline Trimester 2 & 14 & 34.1 \\
\hline Trimester 3 & 18 & 43.9 \\
\hline Total & 41 & 100.0 \\
\hline
\end{tabular}

Berdasarkan tabel 5.5 Karakteristik ibu hamil berdasarkan usia kehamilan di Wilayah Desa Cikunir Kabupaten Tasikmalaya Tahun 2018 sebagian besar adalah trimester III yaitu sebanyak 18 orang $(43.9 \%)$.

Distribusi ibu hamil yang Melakukan Budaya/Tradisi Syukuran Empat Bulanan dan Tujuh Bulanan di Wilayah Desa Cikunir Kabupaten Tasikmalaya Tahun 2018

\begin{tabular}{|c|c|c|}
\hline \multicolumn{3}{|l|}{$\begin{array}{l}\text { Pelaksanaan } \\
\text { Budaya/tradisi }\end{array}$} \\
\hline Tujuh Bulanan & Jumlah & Persentase \\
\hline $\mathrm{Ya}$ & 32 & 78.0 \\
\hline Tidak & 9 & 22.0 \\
\hline Total & 41 & 100.0 \\
\hline
\end{tabular}

Berdasarkan tabel 5.6 Ibu hamil di Wilayah Desa Cikunir Kabupaten Tasikmalaya Tahun 2018 yang melakukan kebiasaan atau tradisi dilingkungan terkait dengan kehamilan sebanyak 32 orang $(78.0 \%)$. 
Distribusi ibu hamil yang Memiliki Pantangan di Wilayah Desa Cikunir Kabupaten Tasikmalaya Tahun 2018

\begin{tabular}{lcl}
\hline $\begin{array}{l}\text { Pantangan } \\
\text { hamil }\end{array}$ & \multicolumn{1}{c}{ Jumlah } & Persentase \\
\hline $\begin{array}{l}\text { Tidak } \\
\text { pantangan }\end{array}$ & ada 6 & 14.6 \\
\hline $\begin{array}{l}\text { Tidak boleh } \\
\text { pisang dari } \\
\text { yang } 1\end{array}$ & $\begin{array}{c}\text { pohon } \\
\text { sudah }\end{array}$ \\
tumbang & 2.4 \\
\hline $\begin{array}{l}\text { Menjawab } \\
\text { Pertanyaan }\end{array}$ & 21 & 2.4 \\
\hline $\begin{array}{l}\text { Menjawab } \\
\text { Pertanyaan }\end{array}$ & 38 & 19.5 \\
\hline $\begin{array}{l}\text { Menjawab } \\
\text { Pertanyaan }\end{array}$ & 42 & 4.9 \\
\hline $\begin{array}{l}\text { Menjawab } \\
\text { Pertanyaan }\end{array}$ & 59 & 22.0 \\
\hline $\begin{array}{l}\text { Menjawab } \\
\text { Pertanyaan }\end{array}$ & 612 & 29.3 \\
\hline $\begin{array}{l}\text { Menjawab } \\
\text { Pertanyaan }\end{array}$ & 71 & 2.4 \\
\hline $\begin{array}{l}\text { Menjawab } \\
\text { Pertanyaan }\end{array}$ & 81 & 2.4 \\
\hline \begin{tabular}{l} 
Total \\
\hline
\end{tabular} & 41 & 100.0 \\
\hline
\end{tabular}

Berdasarkan tabel 5.7 Ibu hamil di Wilayah Desa Cikunir Kabupaten Tasikmalaya Tahun 2018 yang memiliki pantangan makanan selama kehamilan sebagian besar memiliki 6 pantangan makanan yang tidak boleh dikonsumsi yaitu sebanyak 13 orang $(31.7 \%)$.
Distribusi Jenis Pantangan/Larangan Yang Harus Diikuti Ibu Pada Saat Hamil di Wilayah Desa Cikunir Kabupaten Tasikmalaya Tahun 2018

\begin{tabular}{lll}
\hline $\begin{array}{l}\text { Tidak } \\
\text { Pantangan }\end{array}$ & Ada & \\
\hline Setuju & 6 & 14.6 \\
\hline Tidak Setuju & 35 & 85.4 \\
\hline Total & 41 & 100.0 \\
\hline
\end{tabular}

Berdasarkan tabel 5.8 didapatkan bahwa ibu hamil yang tidak setuju tidak ada pantangan sebanyak 35 orang $(85.4 \%)$.

Distribusi Jenis Pantangan/Larangan Yang Harus Diikuti Ibu Pada Saat Hamil di Wilayah Desa Cikunir Kabupaten Tasikmalaya Tahun 2018

\begin{tabular}{lll}
$\begin{array}{l}\text { Jangan Makan } \\
\text { dipiring besar }\end{array}$ & Jumlah & Persentase \\
\hline Setuju & 27 & 65.9 \\
\hline Tidak Setuju & 14 & 34.1 \\
\hline Total & 41 & 100.0 \\
\hline
\end{tabular}

Berdasarkan tabel 5.9 didapatkan bahwa ibu hamil tidak boleh makan dipiring besar yang setuju sebanyak 27 orang (65.9\%).

Distribusi Jenis Pantangan/Larangan Yang Harus Diikuti Ibu Pada Saat Hamil di Wilayah Desa Cikunir Kabupaten Tasikmalaya Tahun 2018

\begin{tabular}{lll}
\hline $\begin{array}{l}\text { Jangan Makan } \\
\text { pisang dari pohon Jumlah } \\
\text { tumbang }\end{array}$ & Persentase \\
\hline Setuju & 24 & 58.5 \\
\hline Tidak Setuju & 17 & 41.5 \\
\hline Total & 41 & 100.0 \\
\hline
\end{tabular}


Berdasarkan tabel 5.9 didapatkan bahwa ibu hamil tidak boleh Makan pisang dari pohon tumbang yang setuju sebanyak 24 orang $(58.5 \%)$.

Distribusi Jenis Pantangan/Larangan Yang Harus Diikuti Ibu Pada Saat Hamil di Wilayah Desa Cikunir Kabupaten Tasikmalaya Tahun 2018

\begin{tabular}{lcl}
\hline $\begin{array}{l}\text { Jangan } \\
\text { Air ES }\end{array}$ & Minum Jumlah & Persentase \\
\hline Setuju & 25 & 61.0 \\
\hline Tidak Setuju & 16 & 39.0 \\
\hline Total & 41 & 100.0 \\
\hline
\end{tabular}

Berdasarkan tabel 5.10 didapatkan bahwa ibu hamil tidak boleh minum air ES yang setuju sebanyak 25 orang $(61.0 \%)$.

Distribusi Jenis Pantangan/Larangan Yang Harus Diikuti Ibu Pada Saat Hamil di Wilayah Desa Cikunir Kabupaten Tasikmalaya Tahun 2018

\begin{tabular}{lll}
\hline $\begin{array}{l}\text { Makan Pedas } \\
\begin{array}{l}\text { Menyebabkan } \\
\text { Bayi Lahir Sakit }\end{array}\end{array}$ & Jumlah & Persentase \\
\hline Setuju & 25 & 61.0 \\
\hline Tidak Setuju & 16 & 39.0 \\
\hline Total & 41 & 100.0 \\
\hline
\end{tabular}

Berdasarkan tabel 5.11 didapatkan bahwa ibu hamil tidak boleh Makan Pedas Menyebabkan Bayi Lahir Sakit setuju sebanyak 25 orang $(61.0 \%)$.
Distribusi Jenis Pantangan/Larangan Yang Harus Diikuti Ibu Pada Saat Hamil di Wilayah Desa Cikunir Kabupaten Tasikmalaya Tahun 2018

\begin{tabular}{lll}
\hline $\begin{array}{l}\text { Tidak } \\
\text { Makan } \\
\text { Duren, Tape }\end{array}$ & \multicolumn{1}{c}{ Boleh } \\
Nanas, Jumlah & Persentase \\
\hline Setuju & 21 & 51.2 \\
\hline Tidak Setuju & 20 & 48.8 \\
\hline Total & 41 & 100.0 \\
\hline
\end{tabular}

Berdasarkan tabel 5.12 didapatkan bahwa ibu hamil tidak boleh Tidak boleh makan nanas, duren, tape setuju sebanyak 21 orang $(51.2 \%)$.

Distribusi Jenis Pantangan/Larangan Yang Harus Diikuti Ibu Pada Saat Hamil di Wilayah Desa Cikunir Kabupaten Tasikmalaya Tahun 2018

Sering Minum Air Jumlah Persentase Kelapa Muda

\begin{tabular}{lll}
\hline Setuju & 25 & 61.0 \\
\hline Tidak Setuju & 16 & 39.0 \\
\hline Total & 41 & 100.0 \\
\hline
\end{tabular}

Berdasarkan tabel 5.13 didapatkan bahwa ibu hamil Sering Minum Air Kelapa Muda setuju sebanyak 25 orang $(61.0 \%)$.

Distribusi Jenis Pantangan/Larangan Yang Harus Diikuti Ibu Pada Saat Hamil di Wilayah Desa Cikunir Kabupaten Tasikmalaya Tahun 2018

\begin{tabular}{lll}
\hline $\begin{array}{l}\text { Sering } \\
\text { Minyak Kelapa }\end{array}$ & \multicolumn{1}{c}{ Minum Jumlah } & Persentase \\
\hline Setuju & 27 & 65.9 \\
\hline Tidak Setuju & 14 & 34.1 \\
\hline Total & 41 & 100.0 \\
\hline
\end{tabular}


Berdasarkan tabel 5.14 didapatkan bahwa ibu hamil Sering Minum Minyak Kelapa Muda setuju sebanyak 27 orang $(65.9 \%)$.

Distribusi Jenis Pantangan/Larangan Yang Harus Diikuti Ibu Pada Saat Hamil di Wilayah Desa Cikunir Kabupaten Tasikmalaya Tahun 2018

\begin{tabular}{lll}
\hline $\begin{array}{l}\text { Minum Madu dan } \\
\text { Kocokan }\end{array}$ & Telur Jumlah & Persentase \\
Ayam & & \\
\hline Setuju & 27 & 65.9 \\
\hline Tidak Setuju & 14 & 34.1 \\
\hline Total & 41 & 100.0 \\
\hline
\end{tabular}

Berdasarkan tabel 5.15 didapatkan bahwa ibu hamil Minum Kocokan telur ayam setuju sebanyak 27 orang $(65.9 \%)$.

\section{E. PEMBAHASAN}

\section{Pelaksanaan Budaya/tradisi Syukuran Empat dan Tujuh Bulanan}

$\begin{array}{ccr}\text { Berdasarkan hasil } & \begin{array}{r}\text { analisis } \\ \text { didapatkan mengenai }\end{array}\end{array}$

Budaya/tradisi Syukuran Empat dan Tujuh Bulanan yang biasa di lakukan pada masa kehamilan di Desa Cikunir masih mempertahankan upacara empat bulanan dan tujuh bulanan karan acara tersebut merupakan acara yang turun temurun dari nene moyang dan acara yang ritual yang dilakukan pada ibu hamil karna pada ibu hamil usia empat bulan merupakan usia ditiupkannya ruh ke dalam janin.

Acara syukuran empat bulanan ini diadakan secara sederhana dengan mengundang tatangga terdekat dan saudarasaudara dengan kegiatan pengajian yang dipimpin oleh Ustadz yang bertujuan untuk mendo'akan agar bayi dan ibunya sehat, normal, dan selamat selama kehamilan dan pada saat persalinan, selain pengajian proses pengajian ini dibacakan Surah Yaasin, Surah
Yusuf dan surah An-nisa pengajian ini bertujuan untuk mendoaakan supaya pesalinanya lancar dan anak yang dilahirkan sehat, sholeh ganteng, sholehah dan cantik, juga dilakukan upacara empat bulanan dan tujuh bulanan ibu hamil juga dimandikan oleh orang tua suami dan keluarga dengan air yang dicampur dengan empat jenis bungabungaan yang sudah di Doakan oleh Ustadz dan paraji. Besar kecilnya penyelenggaraan upacara tidak dinilai oleh masyarakat, yang penting upacara ini dilaksanakan. Kepatuhan terhadap tradisi ini juga terjadi pada masyarakat Buton yang masih mempertahankan upacara posipo(upacara untuk ibu hamil anak pertama) (Hindaryatiningsih: 2016).

Syukuran empat bulanan dan tujuh bulanan ini untuk kegiatanya disesuaikan dengan kemampuan ibu hamil dan keluarganya masing-masing, ada beberapa persyaratan yang harus ada yaitu empat macam empat macam beubeutian (umbi-umbian) yang di kukus. Pada Usia kehamilan tujuh bulanan diadakan upacara yang serupa. Bedanya pada usia kehamilan tujuh bulanan ini buah-buahan yang disediakan untuk dibuat rujak.

Ritual inisiasi menyampaikan pesan simbolis yang menyuarakan nilai dan keyakinan budaya yang sangat dalam (Davis-Floyd: 1992) dan bertujuan untuk melindungi ibu dan janin (dan kadang juga ayah, kerabat dan seluruh keluarga) dari kekuatan jahat (Van Gennep: 2004). Upacara seperti ini juga merupakan bentuk perhatian keluarga dan tetangga serta masyarakat sekitar (Badan Penelitian dan Pengembangan Kesehatan Kementerian Kesehatan RI: 2012) dan juga bertujuan untuk mengenalkan nilainilai kebaikan seperti nilai kebersamaan, nilai respect, nilai sosial yang diwujudkan dalam kerelaan membagikan rizki kepada 
sanak keluarga dan handai taulan yang hadir, sejak anak di dalam kandungan (Hindaryatiningsih : 2016).

Pada masyarakat tradisional, kehamilan dan per-salinan merupakan proses yang normal dan sebagai identitas bagi seorang perempuan (Hillier: 2003). Untuk meyakinkan kesehatan dan keselamatan ibu dan bayinya, masyarakat Desa Karangsari memeriksakan kehamilannya ke bidan dan juga tetap memanfaatkan paraji untuk memeriksa kehamilan, memimpin ritual upacara opat bulanandan nujuh bulanandan juga memberikan saran-saran untuk keselamatan diri dan bayinya.

Hal yang dikemukakan di atas sejalan dengan hasil penelitian Agus et al(2012), Almutahar (2014) dan Choguya (2014) yang mana dukun bersalin memiliki otoritas dalam kehamilan dan persalinan. Dengan demi-kian, masyarakat Desa Karangsari memanfaatkan akses terhadap pelayanan kesehatan dengan tetap mempertahankan praktik-praktik tradisional yang didapatkan secara turun-temurun, sesuai dengan hasil kajian Otoo (2015) dan Choudhury et al(2012).

\section{Pantangan/Larangan Yang Harus Diikuti Ibu Pada Saat Hamil}

\section{Tidak Ada Pantangan}

Berdasarkan hasil analisis didapatkan mengenai Pantangan/Larangan Yang Harus Diikuti Ibu Pada Saat Hamil yang biasa di lakukan pada masa kehamilan di Desa Cikunir didapatkan hasil bahwa $14.6 \%$ ibu hamil tidak mempunyai pantangan dan $85.4 \%$ ibu yang mempunyai pantangan/larangan pada saat hamil. Jadi tidak semua ibu hamil yang berada di wilayah Desa Cikunir menyakini adanya pantangan pada saat kehamilan, itu semua tergantung dari individu masing-masing yang ada di wilayah setempat.
Budaya di masyarakat memiliki resep tentang makanan atau minuman yang tepat untuk memperlancar proses fisiologis kehamilan (Helman:2002) yang diper-caya akan berdampak terhadap kelancaran persalinan dan pasca salin. Anjuran makanan pada ibu hamil di Desa Karangsari sejalan dengan hasil penelitian M'soka et al (2010) di Zambia yang mana ibu hamil meyakini perlunya diet seimbang.

\section{Jangan Makan dipiring besar}

Berdasarkan hasil penelitian didapatkan bahwa responden memiliki persepsi bahwa ibu hamil tidak boleh makan dipiring besar yaitu 27 orang $(65.9 \%)$.

Hal ini tidak sesuai dengan teori dimana kebutuhan gizi ibu hamil merupakan hal yang penting yang harus yang harus dipenuhi selama kehamilan berlangsung. Resiko akan kesehatan janin yang sedang dikandung dan ibu yang mengandung akan berkurang jika ibu hamil mendapatkan gizi dan nutrisi yang seimbang. Oleh karna itu keluarga dan ibu hamil haruslah memperhatikan mengenai hal ini. Gizi atau nutrisi ibu hamil kondisinya sama saja dengan pengaturan gizi mengenai pola makan yang sehat.Kebutuhan gizi ibu hamil meninkat $15 \%$ dibandingkan dengan kebutuhan wanita normal. Peningkatan gizi ini di butuhkan untuk pertumbuhan ibu dan janin. Makanan dikonsumsi ibu hamil 40\% digunakan untuk pertumbuhan janin dan sisanya $60 \%$ digunakan untuk pertumbuhan ibunya. Secara normal kenaikan Berat Badn Ibu Hamil berkisar antara $12-14 \mathrm{~kg}$.

\section{Jangan Makan Pisang dari Pohon yang Tumbang}

Berdasarkan hasil penelitian didapatkan bahwa responden memiliki persepsi bahwa Jangan Makan Pisang dari 
Pohon yang Tumbang yaitu 24 orang (58.5\%). Karna memakan pisang dari pohon yang tumbang dapat mengakibatkan rahimnya keluar ini merupakan keyakinan/tradisi ibu akibat budaya yang diyakininya.

Menurut Susiloningtyas (2007),

Kebutuhan nutrisi salah satunya adalah zat besi selama hamil dengan rata-rata $800 \mathrm{mg}-$ 1040mg. Kebutuhan ini diperlukan untuk : \pm 300mg diperlukan untuk pertumbuhan janin, \pm $50 \mathrm{mg}-75 \mathrm{mg}$ untuk pembentukan plasenta, \pm $500 \mathrm{mg}$ digunakan untuk meningkatkan massa hemoglobin maternal atau sel darah merah, \pm $200 \mathrm{mg}$ lebih akan dieksresikan lewat usus, urin, dan kulit, serta $\pm 200 \mathrm{mg}$ lenyap ketika melahirkan.

Pisang sejak lama telah dikenal sebagai buah lezat dan berkhasiat bagi kesehatan. Buah pisang mengandung kalium (potasium) yang bermanfaat untuk penyeimbangan $\mathrm{pH}$ atau derajat keasaman didalam lambung (Lalage, 2013). Selain itu, kalium. bermanfaat untuk pengendalian tekanan darah, memengaruhi irama jantung, terapi darah tinggi, membersihkan karbondioksida didalam darah, berperan dalam kepekatan saraf dan otot, serta memicu kerja otot dan simpul saraf (Astrawan, 2008). Kalium yang tinggi juga akan memperlancar pengiriman oksigen ke otak dan membantu keseimbangan cairan di dalam tubuh (Kowalski, 2010).

\section{Jangan Minum Air ES}

Berdasarkan hasil penelitian didapatkan bahwa responden memiliki persepsi bahwa ibu hamil yang mengkonsumsi Air es beresiko bahwa bayi yang dikandungnya anak lahir tidak normal (bayi besar) sebanyak 25 responden $(61.0 \%)$.

Hal ini tidak sesuai dengan teori yang menyebutkan bahwa ibu yang mengkonsumsi air es atau minuman dingin selama masa kehamilan seperti es krim, sirup dan minuman yang lainya mengandung es akan melahirkan bayi dengan ukuran yang lebih besar dibandingkan pada berat yang normal. Padahal air es dan bayi tidak ada hubunganya sama sekali. Bayi besar atau yang disebut dengan makrosomia ini adalah dimana kondisi bayi yang lahir dengan berat badan lebih dari 4 $\mathrm{kg}$. Hal ini umumnya di sebabkan oleh ibu hamil yang mengidap penyakit diabetes (kencing manis).

Ibu yang mengkonsumsi air es selama kehamilan tidak berpengaruh dengan bayi besar, yang dapat menyebabkan bayi besar apabila ibu hamil mengkonsumsi air es ditambah dengan pemanis (gula, sirup dan yang lainya).

Pemanis merupakan senyawa kimia yang sering digunakan untuk keperluan produk olahan pangan, industri serta minuman dan makanan kesehatan. Menurut Peraturan Menteri Kesehatan (Menkes) RI Nomor 235, pemanis termasuk ke dalam bahan tambahan kimia, selain zat yang lain seperti antioksidan, pemutih, pengawet, dan lain sebagainya. Pemanis berfungsi untuk meningkatkan cita rasa dan aroma, memperbaiki sifat-sifat fisik, sebagai pengawet, dan untuk memperbaiki sifat-sifat kimia sekaligus merupakan sumber kalori bagi tubuh.

\section{Makanan Pedas menyebabkan Bayi Lahir Sakit}

Berdasarkan hasil penelitian didapatkan bahwa responden memiliki persepsi bahwa ibu hamil yang mengkonsumsi Makanan Pedas menyebabkan Bayi Lahir Sakit sebanyak 25 responden $(61.0 \%)$.

Hal ini tidak sesuai dengan teori yang menyatakan bahwa makanan pedas tidak baik dikonsumsi oleh ibu hamil. Berikut dampak makanan pedas bagi ibu hamil :

a. Heartburn

Salah satu bahaya yang bisa ditimbulkan jika ibu hamil sering makanmakanan yang pedas akan mengalami 
heartburn adalah kondisi dimana dada terasa sesak dan nafas setelah makan. Makanmakanan yang pedas selama masa kehamilan bisa menyebabkan anda mengalami heartburn dan juga bisa meningkatkan asam lambung.

b. Moorning Sickness

Bahaya jika ibu terlalu sering makan-makanan pedas selama masa kehamilan yang kedua adalah bisa memperburuk morning sickness yang ibu alami. Morning sickness ini diiringi gejala seperti mual, muntah, pusing, perut tak nyaman dan bisa jadi tambah parah jika ibu makan-makanan pedas. Ibu hamil juga harus tahu bagaimana cara mengatasi Morning sickness.

c. Maag

Bagi ibu yang suka makan pedas dalam keadaan ibu sedang hamil lebih besar beresiko terkena maag atau asam lambung.

d. Perut terasa tidak nyaman

Perut terasa tidak nyaman atau perut terasa mulas karna makanan yang di konsumsi ibu hamil makanan pedas bisa membuat ibu terkena sakit perut yang disertai dengan gejala infeksi. Jika sudah sangat parah maka akan menyebabkan diare yang berlebihan.

e. Kontraksi

Makanan pedas bisa membantu meningkatkan pelepasan hormon prostaglandin yang mana bisa menyebabkan otot menginduksi sehingga bisa menyebabkan kontraksi. Kontraksi ini akan kita rasakan seperti mau melahirkan.

Hal ini sesuai dengan hasil penelitian Sinta Fitriani, S.KM, M.KM dalam Jurnal Kesehatan Bidkesmas Respati, Volume 1, Nmor 10 Februari 2019 "Berdasarkan hasil penelitian didapatkan bahwa responden memiliki persepsi bahwa ibu hamil yang mengkonsumsi makanan pedas mendapatkan anak dengan muka dengan kemerahan yaitu 105 orang (64\%).

\section{Tidak Boleh Makan Nanas, Duren dan Tape}

Berdasarkan hasil penelitian didapatkan bahwa responden memiliki persepsi bahwa ibu hamil tidak boleh makan Nanas, Duren dan tape sebanyak 21 responden (51.2\%).

Masyarakat di Desa Cikunir mempunyai pantangan tidak meboleh makan Nanas, Duren dan Tape karna makanan tersebut membuat ibu hamil terjadi keguguran, pantangan ini sudah dari turun temurun nenek moyangnya.

Buah yang hampir ditabukan oleh berbagai suku/daerah di Indonesia adalah buah nenas. Masyarakat percaya bahwa ibu hamil yang mengonsumsi buah nanas akan menyebabkan keguguran, "Landep", menyebabkan korengan, diare, proses persalinan akan sulit dan kulit bayi bersisik, gatal, kepala anak seperti nanas, menyebabkan panas pada janin, anak akan membesar sehingga sulit saat persalinan, dan membahayakan janin. Buah nanas mengandung enzim bromelin yang dapat menstimulasi pengeluaran prostaglandin. Kadar prostaglandin yang meningkat dapat menyebabkan stimulasi kontraksi uterus. Selain itu, buah nanas juga mengandung serotonin yang juga memiliki peran dalam merangsang kontraksi uterus.

Duren mengandung senyawa sulfur yang disebut dietil disulfida yang dapat menghambat kerja enzim aldehyde dehydrogenase (ALDH) dalam hati yang berfungsi untuk memecah alkohol. Ditambah lagi, durian sudah tinggi kalori, jadi menambahkan alkohol akan membuat hal sulit bagi perut dan hati untuk mencerna makanan. Hal ini dapat menyebabkan gejala hangover yang berlebihan. Kadar alkohol dalam darah yang gagal dipecah oleh tubuh, karena dihambat oleh durian akan berubah menjadi sangat beracun. Anda dapat menjadi sangat kebingungan, tidak responsif, mengalami pernapasan pendek, bahkan kehilangan kesadaran hingga koma. Selain itu, meski durian tidak mengandung kolesterol dan lemak jenuh, makan durian tetap bisa meningkatkan tekanan darah. Kadar 
alkohol yang terlalu tinggi dalam tubuh bisa makin menyebabkan tekanan darah Anda melonjak di luar batas. Hipertensi kemudian meningkatkan risiko Anda mengalami serangan jantung, stroke, atau gagal jantung kongestif.

Tingkat alkohol dalam darah yang melebihi batas wajar juga dapat melemahkan otot-otot jantung, yang juga akan mempengaruhi paru, hati, otak, dan sistem organ dalam tubuh lainnya. Kadar alkohol yang terlalu tinggi dalam darah dapat menyebabkan kerusakan otak permanen dan menyebabkan jantung berdetak tidak normal (aritmia jantung), yang telah dikaitkan dengan kematian mendadak.

Kandungan dalam tape terdapat kadar alkohol yang dikandungnya, dapat menyebabkan terjadinya faktor resiko mengalami penyakit hati. Hal ini dikarenakan alkohol dimetabolisme di dalam organ hati, sehingga membuat organ hati bekerja lebih berat. Penyakit hati paling sering terjadi akibat kebiasaan mengkonsumsi alkohol adalah sirosis hati. Walaupun ada yang mengatakan bahwa kandungan alkohol dari tape tidak begitu besar, namun tetap saja hal tersebut akan menjadi akumulasi pada saat sering dikonsumsi. Selain itu dalam beberapa pendapat mengatakan, bahwa ketika mengkonsumsi tape singkong selain dapat menyebabkan resiko penyakit hati pada Ibu hamil, diduga juga dapat merusak atau memicu gangguan hati juga pada janin. Hal ini dikarenakan setelah Ibu mengkonsumsi tape, maka alkohol di kangdungannya akan terbawa di dalam darah dan kemudian menembus plasenta lalu masuk ke tubuh janin. Dari situ di dalam tubuh janin, organ hatinya juga akan ikut dalam proses metabolisme alkohol sehingga ketika bayi lahir, bisa saja bayi mengalami gangguan fngsi hati dan tampak kuning.

Beberapa penelitian telah membuktikan bahwa terdapat hubungan yang signifikan antara konsumsi nanas muda dengan kontraksi uterus. Namun prinsipnya, kandungan bromelin akan menurun seiring dengan bertambahnya tingkat kematangan nanas. Hasil penelitian Apsari et al.(2012) menunjukkan terdapat hubungan yang signifikan antara pemberian ekstrak buah nanas baik yang muda ataupun tua terhadap kontraksi uterus marmut. Namun, pemberian ekstrak buah nanas muda lebih kuat pengaruhnya terhadap peningkatan kontraksi uterus dibandingkan ekstrak buah nanas tua. Mungkin, hal inilah yang dapat menjelaskan secara ilmiah mengapa konsumsi buah nanas ditabukan bagi ibu hamil. Tetapi, menurut hasil penelitian Sari, kebiasaan mengonsumsi buah nanas oleh ibu di atas usia kehamilan di atas 36 minggu dapat dilakukan dengan catatan ibu hamil normal tanpa komplikasi dan ibu hamil yang usia kehamilannya sudah matur (Sari, 2010).

\section{Sering Minum Air Kelapa Muda}

Berdasarkan hasil penelitian didapatkan bahwa responden memiliki persepsi bahwa ibu hamil yang sering minum air kelapa muda yang setuju sebanyak 25 responden $(61.0 \%)$ dan tidak setuju 16 responden $(39.0 \%)$.

Pada masyarakat ini beramsumsi bahwa ibu hamil yang sering minum air kelapa muda sangat bagus untuk kehamilan terutama pada kehamilan usia 4 bulan ke atas, meraka beramsusi bahwa kandungan dalam air kelapa muda bagus untu janin dan untuk memperbanyak air ketuban pada kehamilan ibu.

Selama menjalani masa kehamilan, ibu hamil bisa mengonsumsi air kelapa karena memiliki sejumlah manfaat bagi ibu dan janin. Manfaat tersebut antara lain :

\section{Sumber elektrolit dan antioksidan}

Air kelapa mengandung elektrolit, minum air kelapa bisa mengganti asupan elektrolit yang terbuang saat muntah pada ibu hamil yang mengalami morning sickness. Air 
kelapa pun mengandung antioksidan yang membantu melenyapkan radikal bebas di tubuh. Untuk hasil yang maksimal, pilihlah air kelapa segar, bukan air kelapa kemasan.

\section{Membantu mengurangi kelelahan}

Kandungan elektrolit dalam air kelapa sangat baik dalam mengganti cairan tubuh yang hilang sehingga ibu hamil terhindar dari dehidrasi. Garam alami pada tubuh dapat digantikan dengan air kelapa karena mengandung garam alami seperti natrium, kalium, dan klorida.

\section{Mencegah infeksi saluran kencing}

Keluhan yang cukup sering dialami ibu hamil adalah infeksi saluran kencing karena adanya perubahan hormon dan perkembangan rahim yang menekan kandung kemih. Air kelapa adalah diuretik alami yang akan membuat ibu hamil lebih mudah untuk mengeluarkan urine dan mencegah terjadinya infeksi saluran kemih. Beberapa wanita terbantu dalam mencegah infeksi saluran kemih dengan mengonsumsi air kelapa.

\section{Melancarkan sirkulasi darah}

Air kelapa untuk ibu hamil juga berguna untuk mengurangi pegal dan nyeri yang diakibatkan tidak optimalnya sistem sirkulasi darah. Jika sistem sirkulasi darah tidak optimal, maka janin berisiko tidak mendapatkan suplai oksigen yang cukup. Kalium dan magnesium yang terdapat dalam air kelapa berperan penting dalam memompa darah ke seluruh tubuh dari jantung. Kalium juga membantu gerakan otot, penghantaran sinyal saraf, dan membantu kerja ginjal dalam penyaringan darah.

Menurut Kemala dan Velayutham (1978), nilai gizi pada air buah kelapa muda, terutama mineral komposisi tertinggi adalah pada umur buah 8 bulan dan mineral $\mathrm{K}$ adalah yang paling tinggi. Oleh karena itu berbagai penelitian menunjukkan bahwa penggunaan air kelapa dapat menyembuhkan beberapa penyakit. Jika ditelusuri susunan komposisi gizi dari jenis-jenis susu formula, maka hampir semua komposisi makro maupun mikronutrien pada daging dan air kelapa muda, terkandung pada susu formula.

\section{Sering Minum Minyak Kelapa}

Berdasarkan hasil penelitian didapatkan bahwa responden memiliki persepsi bahwa ibu hamil yang sering minum minyak kelapa yang setuju sebanyak 27 responden $(65.9 \%)$ dan tidak setuju 14 responden (34.1\%).

Pada masyarakat ini beramsumsi bahwa ibu hamil yang sering minum minyak kelapa sangat bagus untuk melancarkan kelahiranya karna minum minyak kelapa akan membuat persalinan menjadi lancar karna banyak mengandung minyak.

Buah kelapa memilki cukup banyak manfaat, yaitu sebagai minyak makan atau santan dalam sayur-sayuran. Minyak kelapa murni mengandung asam laurat yang tinggi. Asam laurat adalah asam lemak jenuh yang berantai medium atau biasa disebut Medium Chain Fatty Acid (MCFA). Dalam minyak kelapa murni terkandung energi sebanyak 6,8 kal/gr dan MCFA sebanyak 92\% (Gani, 2005).

Saat ini minyak kelapa banyak digunakan sebagai obat. Minyak kelapa yang dijadikan sebagai obat biasanya disebut minyak kelapa murni (virgin coconut oil/ VCO). Berbagai penyakit yang berasal dari virus dapat ditangkal dengan mengkonsumsi minyak kelapa murni, seperti flu burung, HIV/AIDS, hepatitis, dan jenis virus lainnya. Selain itu, minyak kelapa murni dapat juga mengatasi kegemukan, penyakit kulit, darah tinggi, dan diabetes (Sutarmi dan Rozaline, 2005).

Menurut SNI 7381:2008 minyak kelapa murni adalah minyak yang diperoleh dari daging buah kelapa 
(Cocos nucifera L.) tua yang segar dan diproses dengan diperas dengan atau tanpa penambahan air, tanpa pemanasan atau pemanasan tidak lebih dari 600C dan aman untuk dikonsumsi. Minyak kelapa murni tidak berwarna (bening), tidak berasa, serta mempunyai aroma yang harum dan khas (Gani, 2005).

Minyak kelapa murni mempunyai sifat tahan terhadap panas, cahaya, oksigen, dan proses degradasi. Sifat itu membuat minyak kelapa murni dapat disimpan dalam jangka waktu yang lama. Dalam pemanfaatannya, minyak kelapa murni dapat dikonsumsi secara langsung ataupun dicampur dengan makanan (Gani, 2005).

VCO mempunyai kandungan asam lemak jenuh yang tinggi. VCO mengandung sekitar $92 \%$ asam lemak jenuh yang terdiri dari asam laurat, miristat, dan palmitat. Kandungan asam lemak jenuh dalam VCO didominasi oleh asam laurat dan asam miristat, sedangkan kandungan asam lemak lainnya rendah. Tingginya asam lemak jenuh yang dikandungnya menyebabkan VCO tahan terhadap proses ketengikan akibat oksidasi (Syah, 2005).

\section{Minum Madu dan Kocokan Telur Ayam}

Berdasarkan hasil penelitian didapatkan bahwa responden memiliki persepsi bahwa ibu hamil yang Minum Madu dan Kocokan Telur Ayam yang setuju sebanyak 27 responden $(65.9 \%)$ dan tidak setuju 14 responden $(34.1 \%)$.

Pada masyarakat ini beramsumsi bahwa ibu hamil yang sering minum madu dan kocokan telur ayam sangat bagus untuk kehamilan terutama pada pada bayi yang didalam kandungan ibu dan ibu hamilpun akan merasa sehat dan stamina yang kuat selama kehamilan dan persiapan untuk persalinanya.

Madu merupakan salah satu sumber makanan yang baik. Madu bermanfaat sebagai makanan kesehatan yang dapat meningkatkan stamina tubuh sebagai energi seketika. Selain itu madu juga dapat digunakan sebagai pengganti gula atau suplementasi nutrisi. Produk lebah ini dapat menyembuhkan berbagai macam penyakit seperti jantung, paruparu, lambung, sistem pencernaan, influenza, katarak, luka infeksi, dan masih banyak lagi khasiat dari madu. Gula dan mineral dalam madu berfungsi sebagai tonikum bagi jantung. Antioksidan madu diyakini mampu mencegah terjadinya kanker, penyakit jantung, dan penyakit lainnya. Selain itu madu juga dapat membunuh dan mencegah kuman untuk berkembang sehingga madu dipercaya dapat menyembuhkan berbagai macam luka seperti luka bakar, luka infeksi, luka setelah operasi dan lain-lain. Madu juga banyak sekali digunakan dalam dunia kosmetika, baik dalam bentuk sabun, masker, dan krim pelembut. Madu dapat menjaga kelembaban kulit dan memberinya nutrisi yang dibutuhkan. Komposisi kimia madu bervariasi tergantung pada sumber tanaman, musim dan metode produksi. Kondisi penyimpanan juga bisa mempengaruhi komposisi akhir, dengan peningkatan proporsi disakarida selama waktu penyimpanan berlangsung. Fruktosa (sekitar 38\% w/w) dan glukosa (sekitar $31 \%$ ) adalah dua gula utama yang terdapat pada madu secara umum, dengan jumlah sukrosa yang kurang (sekitar 1\%), serta disakarida dan oligosakarida yang lain. Potassium merupakan mineral utama pada madu. Selain itu mineral yang juga terkandung dalam madu adalah $\mathrm{Ca}, \mathrm{P}, \mathrm{Fe}, \mathrm{Mg}$, dan Mn. Madu mengandung beberapa vitamin antara lain vitamin $\mathrm{E}$ dan vitamin $\mathrm{C}$ serta vitamin B1, B2 dan B6. Madu memiliki keasaman yang rendah 
dengan $\mathrm{pH}$ sekitar 3,9. Kandungan air madu sekitar 17\%, dengan aktivitas air antara 0,56-0,62. Asam glukonat dan jumlah protein yang kecil serta asam amino juga terdapat pada madu.

Madu mengandung beberapa senyawa organik, yang telah terindentifikasi antara lain seperti polyphenol, flavonoid, dan glikosida. Selain itu, di dalam madu juga terdapat berbagai jenis enzim, antara lain enzim glukosa oksidase dan enzim invertase yang dapat membantu proses pengolahan sukrosa untuk diubah menjadi glukosa dan fruktosa yang keduanya mudah diserap dan dicerna. Begitu pula enzim amilase dan enzim lipase dan minyak volatil, seperti hidroksi metil furfural. Madu juga mengandung dekstrosa (gula yang ditemukan dalam tumbuhan), lilin, gen pembiakan, dan asam formik (Fitri, 2010: 51).

Telur ayam mempunyai struktur yang sangat khusus. Telur dihasilkan dari pembuahan sel telur pada hewan betina oleh sperma yang dihasilkan dari hewan jantan. Karena embrio yang terbentuk bertujuan untuk membentuk keturunan baru, isi telur terdapat bahan-bahan atau at-zat yang sama dengan hewan terbentuknya. Bentuk telur unggas bermacam-macam, umumnya telur memiliki bentuk yang bulat sampai lonjong. Perbedaan bentuk telur disebabkan dari beberapa factor antara lain : 1. Jenis hewan 2. Umur hewan 3. Sifat-sifat fisiologis hewan Semua jenis telur memiliki struktur yang sama. Secara garis besarnya cangkang telur (kerabang), membrane telur, putih telur, kalaza dan kuning telur (Ponimin, 2006: 13).

Pada telur ayam sebagian besar terdiri dari bahan organik, pada putih telur komponen terbanyak adalah air disusul dengan protein, dan pada kuning telur bagian terbanyak juga air, lemak dan protein.

Telur sebetulnya telah memiliki zat anti bakteri secara alami. Lisozim, yakni suatu zat bakterisida, yang terkandung dalam putih telur dan mampu menghancurkan bakteri. Selain itu, putih telur juga mengandung zat yang berdaya mengikat-besi (media pertumbuhan beberapa spesies pseudomonas). Telur mentah mengandung pula avidin yang dapat mengikat biotin. Biotin berperan sebagai factor pertumbuhan beberapa jasad renik (Arisman, 2009: 8).

Telur mengandung berbagai macam zat gizi yang penting bagi tubuh. Gizi telur sebenarnya berpusat pada kuning telur yang tinggi akan kadar protein, lemak, kalsium, fosfor, zat besi dan vitamin (Khamsan, 2004: 114). "Telur merupakan sumber protein bermutu tinggi, kaya vitamin dan mineral. Protein telur termasuk jenis protein sempurna karena mengandung semua jenis asam amino esensial dalam jumlah cukup dan seimbang. Asam amino esensial ini amat penting bagi manusia karena mutlak diperlukan tubuh tapi tidak dapat dibentuk sendiri oleh tubuh. Oleh karena itu, harus dipenuhi dari makanan. Telur mengandung protein lebih dari $10 \%$, bahkan sebutir telur ayam mengandung protein $12,8 \%$. Di dalam telur juga terdapat aneka vitamin A, B, D, E dan K. Telur tergolong makanan yang paling mudah dicerna. Nilai biologis protein telur 96 $\%$. Artinya sejumlah itulah protein yang dapat diserap dan dimanfaatkan tubuh" (Haryoto, 1996: 9).

\section{F. KESIMPULAN DAN SARAN}

\section{Kesimpulan}

Berdasarkan hasil penelitian didapatkan bahwa :

a. Masyarakat yang melaksanakan Budaya/Tradisi Syukuran Empat Bulanan dan Tujuh Bulanan yaitu 
32 orang $(78.0 \%)$.

b. Ibu hamil memiliki pantangan/larang yang harus diikuti ibu hamil pada saat hamil yaitu Tidak setuju 35 orang (85.4 $\%)$.

c. Ibu hamil Jangan makan di piring besar yaitu sebanyak setuju 27 orang $(65.9 \%)$.

d. Ibu hamil jangan makan pisang dari pohon tumbang yaiyu sebanyak setuju 24 orang $(58.5 \%)$.

e. Ibu hamil jangan Minm Air ES yaitu sebanyak setuju 25 orang $(61.0 \%)$.

f. Ibu hamil memakan makanan pedas menyebabkan bayi lahir sakit yaitu sebanyak setuju 25 orang $(61.0 \%)$, Ibu hamil tidak boleh makan nanas, dure, dan tape yaitu sebanyak setuju 21 orang $(51.2 \%)$.

g. Ibu hamil sering minum air kelapa muda yaitu setuju 25 orang $(61.0 \%)$.

h. Ibu hamil sering minum minyak kelapa yaitu setuju 27 orang (65.9\%).

i. Ibu hamil yang minum madu dan kocokan telur ayam yaitu setuju 27 orang $(65.9 \%)$.

\section{SARAN}

a. Petugas Kesehatan

Petugas Kesehatan lebih meningkatkan upaya penyebaran informasi kesehatan kepada masyarakat dengan mendesain pesan dengan pendekatan budaya yang setempat agar bisa merubah budaya lebih baik lagi.

b. Masyarakat

Masyarakat lebih meningkatkan kunjungan Antenatal Care ke petugas kesehatan yang berada di daerah sekitar dan lebih meningkatkan upaya pencarian informasi kesehatan melalui berbagai aktifitas seperti : Kelas ibu hamil, penyuluhan dalam forum pertemuan masyarakat. 


\section{G. DAFTAR PUSTAKA}

Anderson, B.F. 1980. The Complete Thinker: A Handbook of Theniques For Creative and Critical Problem Solving. New Jersey: Englewood Cliffs.

Arikunto, S., 2009. Prosedur Penelitian Suatu Pendekatan Praktik. Edisi Revisi 6. Jakarta : Rineka Cipta.

Ai Yeyeh, R. 2009. Asuhan Kebidanan I (Kehamilan). Jakarta: Trans Info Media.

Ambarwati, S. 2008. Asuhan Kebidanan pada Masa Kehamilan. Salemba Medika.

Ambarwati, W. N. 2006. Pendidikan Kesehatan Mengatasi Keluhan Hamil pada Ibu-Ibu Hamil di Asrama Group II Kopasus Kartasura. Penelitian Reguler Universitas Muhammadiyah Surakarta. Tidak dipublikasikan

Arief, Nurhaeni. 2008. Panduan Lengkap Kehamilan Dan Kelahiran Sehat. Jogjakarta : AR Group

Achmad, Sri Wintala. 2014. Pamali dan Mitos Jawa. Yogyakarta: Araska

Badrujaman, 2008. Sosiologi Untuk Mahasiswa Keperawatan.Trans Info Media. Jakarta

Bayuandhy, Gesta. (2015). Tradisitradisi Adiluhung Para Leluhur Jawa : Melestarikan Berbagai Tradisi Penuh Makna. Yogyakarta : Dipta.

Boy Suzanto, Ari Solihin. 2012. Pengaruh budaya organisasi, komunikasi interpersonal dan komitmen organisasi terhadap kinerja pegawai pada Unit Network Management System Infratel PT. Telekomunikasi Indonesia Tbk. Jurnal ekonomi, bisnis \& entrepreneurship, vol. 6, No. 2, oktober, 64-76.

Cicourel, Aaron V. (2013). Origin and Demise of Social-cultural Presentation of Delf from Birth to Death: Caregiver „Scafoldingee Practices Necessary for Guilding and Sustaining Communal Social Structure Throughout the Life Cycle. British Social Association. 2013.47:51.
Depkes RI. 2006. Profil Kesehatan Indonesia 2006. Jakarta

Dumatubun, A E, 2002, KebudayaKesehatan Orang Papua Dalam Perspektif Antropologi Kesehatan, Jurnal Antropologi Papua Vol 1 No.1.

Dumatubun, AE. (2002). Kebudayaan, Kesehatan Orang Papua Dalam Perspektif Antropologi Kesehatan. Jurnal Antropologi Papua Agustus 2002. Jurusan Antropologi Fakultas Ilmu Sosial dan Ilmu Politik Universitas Cendrawasih.

Depkes RI. 2007. Keputusan Mentri Kesehatan RI No: 900/MENKES/VII/2007. Konsep Asuhan Kebidanan. Jakarta.

Depok: Pusat Penelitian Kesehatan Lembaga Penelitian Universitas Indonesia

Devy S. Hakimi, Prabandari, dan Mardikanto 2011. Perawatan Kehamilan dalam Perspektif Budaya Madura di Desa Tambak dan Desa Rapalaok Kecamatan Omben Kabupaten Sampang : Jurnal Promosi Kesehatan Vol 1, No.1, : 50-62.

Damayanti R.S., 2003. Childhood obesity : evaluation and management. Dalam Soebagijo A., Sri M., Askandar T., Hendromartono., Ari S., Agung P., eds. Naskah Lengkap National Obesity Simposium II 2003. Surabaya: ISSN h. 12337.

Depkes RI. Rencana Strategis Nasional Making Pregnancy Safer (MPS) di Indonesia 2001-2010. Jakarta: Departemen Kesehatan Republik Indonesia; 2001.

Iskandar, Meiwita B. 1996. Mengungkap Misteri Kematian Ibu di Jawa Barat, Depok.

Johnson, J.Y. (2016). Keperawatan Maternitas DeMYSTiFieD Buku Wajib Bagi Praktisi dan Mahasiswa Keperawatan. Penerjemah : Diana Kurnia S. Yogyakarta : Rapha Publishing

Kuswanti, Ina.S. Si. T, M. Kes. 2014. Asuhan kehamilan. Yogyakarta : PT. Pustaka Pelajar

Koentjaraningrat.2005. Pengantar Antropologi II Pokok - Pokok Etnografi, Jakarta: Rineka Cipta,

Lubis, Z. (2003) Posted: 7 November. Status Gizi Ibu Hamil Serta 
Pengaruhnya Terhadap Bayi Yang Di

Lahirkan.

Source:http://pustaka.ictsleman.net/how/k/k esehatan/12_status_gizi_ibu_hamil.

Mulyana, Deddy. Komunikasi Antar Budaya : Panduan Berkomunikasi Dengan Orangorang Berbeda Budaya. Bandung: Remaja Rosdakarya, 2001.

Mulyana,

Deddy.2002.Ilmu

Komunikasi : Suatu Pengantar.Bandung :

PT Remaja Rosdakarya

Mansjoer, Arif dkk. 2005. Kapita Selekta Kedokteran Edisi ketiga Jilid 1 Cetakan keenam. Jakarta: Media Aesculapius Fakultas Kedokteran UI.

Mufdlilah. (2009). Antenatal Care

Fokus. Yogyakarta: Nuha Medika

Niven, Neil. 2002. Psikologi Kesehatan Keperawatan Pengantar untuk Perawat dan Profesional Kesehatan lain. Jakarta: EGC.

Notosoedirjo, M. \& Latipun. (2002).

Kesehatan mental: konsep dan penerapan. Universitas Muhammadiyah Malang.

Notosoedirjo, Moeljono dan Latipun, Kesehatan Mental Konsep \& Penerapan, (Malang, Penerbit Universitas Muhammadiyah Malang, 1999).

O'neil, M.J. et al. 2006. The Merck Index, Merck Sharp and Dohme Corp., a susidiary of Merck and Co., Inc. New York.

Prawirohardjo. 2009. Ilmu

Kebidanan. Jakarta : Bina Pustaka Sarwono Prawirohardjo

Prawirohardjo. 2010. Ilmu

Kebidanan. Jakarta : Bina Pustaka Sarwono Prawirohardjo

Praditama,

Dian

Agustina.(2011).Pola Makan Pada Ibu Hamil Dan Pasca Melahirkan Di Desa Tiripan Kecamatan Berbek Kabupaten Nganjuk. Universitas Airlangga, Surabaya.

Roesli. Utami, 2000. Inisiasi Menyusui Dini Plus ASI Eksklusif. Jakarta; Pustaka Bunda

Rofi'i, $\quad$ Muhamad. 2013. "Kepercayaan Wanita Jawa Tentang Perilaku atau Kebiasaan yang Dianjurkan dan Dilarang Selama Masa Kehamilan" dalam Prosiding Seminar Nasional,
Semarang: UNIMUS, halaman 116 - 120 diunduh melalui situs http://id.portalgaruda.org/index.php?ref=br owse \&mod=viewarticle \&article $=98522$.

Sulismadi dan Sofwani, Ahmad. 2011. Ilmu Sosial dan Budaya Dasar. Malang: UMM Press.

Soekanto, Sudjono. (2006). Sosiologi

Suatu Pengantar. Jakarta: PT. Raja Grafindo Persada

Sinta, Fitriani. (2019). Jurnal Kesehatan BIDKESMAS RESPATI : Volume 1, Nomor 10 Februari 2019.

Herimanto \& Winarno. (2008). Ilmu Sosial Dan Budaya Dasar. Jakarta : PT. Bumi Aksara

Handayani, Sri., 2010. Buku Ajar Keluarga Berencana. Yogyakarta; Pustaka Rihama.

Syafrudin. (2009). Sosial Budaya Dasar Untuk Mahasiswa Kebidanan. Jakarta : Trans Info Media

Sutrisno Edy, 2010. Budaya Organisasi. Kencana Prenada Media Group. Jakarta.

Saptandari, P. (2012). Faktor Sosial Budaya dalam Masalah Kesehatan dan Gizi di Jawa Timur. Dalam http://pinky saptandari-

fisip.web.unair.ac.id/artikel detail-67565 antropologi $\% 20$ kesehatan-

Gizi\%20\&\%20Budaya.html. yang diiunduh tanggal 24 September 2018 pukul 16.22.

Swasono, M. F. (1998). Kehamilan, Kelahiran, Perawatan Ibu dan Bayi Dalam Konteks Budaya. Jakarta : UI Press

Setyanti C,2013. Ibu Hamil Hendaknya Hindari Pijat Perut. famale. kompas.com $/ \mathrm{read} / 2013 / 05 / 21 / 21451610 / \mathrm{Ib}$ u.Sebaiknya.Hindari.Pijat.Perut.

Diakses23Pebruari 2015.

Surbakti, E. B. (2009). Kenalilah Anak Remaja Anda. Jakarta: PT. Alex Media Komputindo.

Suryawati, Chriswardani. 2007. Faktor sosial budaya dalam praktik perawatan kehamilan, persalinan, dan pacsa persalinan (studi di kecamatan bangsri kabupaten jepara). Jurnal promosi kesehatan Indonesia vol. 2/no.1 
Khasanah. 2011. ASI atau susu formula ya?. Panduan Lengkap Seputar ASI dan Susu Formula. Jogjakarta. Flashbook.

Khairunnisa, Anita dan Nindyas Primadini. 2011. Meracik Selai Rumahan. Bandung: Amalia Book.

Reeder SJ. 1997. Maternity Nursing, Family, New Born, And Women's Health Care. Edisi 18. Lippincott,Philadelphia.

$$
\text { Rofi'i Muhammad (2013). }
$$

Kepercayaan Wanita Jawa tentang Perilaku atau Kebiasaan yang Dianjurkan dan Dilarang Selama Masa Kehamilan. Prosiding Konferensi Nasional PPNI Jawa Tengah.

Rukiah dan Yulianti, 2014. Asuhan Kebidanan Kehamilan Berbasis Kompetensi. Jakarta,CV.Trans Info Media

Rukiah dan Yulianti , 2014. Asuhan Kebidanan Kehamilan Berbasis Kompetensi. Jakarta,CV.Trans Info Media.

Sholihah, Lini Anistatus; Sartika, Ratu Ayu Dewi. 2014. "Makanan Tabu pada Ibu Hamil Suku Tengger" dalam Jurnal Kesehatan Masyarakat Nasional. Vol. 8 No. 7 Februari, halaman 319 - 324 . Jakarta: Universitas Indonesia diunduh melalui situs http://id.portalgaruda.org/?ref=browse\&mo $\mathrm{d}=$ viewarticle \&article $=269662$.

Solihah. L. (2010). Panduan Lengkap Hamil Sehat. Yogyakarta:Diva Press

Kartono, Kartini, 1992, Pathologi sosial 2 ( kenakalan remaja). Jakarta: Raja Grafindo Persada.

Sulistyawati, Ari. 2013. Pelayanan Keluarga Berencana. Jakarta : Salemba Medika.

Yulifah, R., Johan, T. A. Y. 2009. Asuhan Kebidanan Komunitas. Salemba Medika, Jakarta

Kusmiyati, Yuni, dkk. 2009. Perawatan Ibu Hamil. Yogyakarta : Fitramaya.

Prawirohardjo, Sarwono., (2005). Ilmu kebidanan. Jakarta : Yayasan Bina Pustaka. Yulifah, R., Johan, T. A. Y. 2009. Asuhan Kebidanan Komunitas. Salemba Medika, Jakarta
Meilani, Niken dkk. 2009. Kebidanan Komunitas. Yogyakarta : Fitramaya. Wiyati, P., \& Wibowo, B. (2013). Luaran Maternal dan Perinatal pada Hamil dengan Penyakit Jantung di RSUP Dr . Kariadi Semarang. Majalah Obstetri \& Ginekologi, 21(1), 20-30. Diakses pada 03 November 2018. http://journal.unair.ac.id/downloadfullpapers-mog4b9ed3cfull.pdf Lubis, Z. 2003. Status Gizi Ibu Hamil Serta Pengaruhnya Terhadap Bayi Yang Dilahirkan. Pengantar Falsafah Sains (PPS702) Program Pasca Sarjana S3 IPB November 2003. Bogor.

Lubis, Zulhaida. 2003. Jurnal Status Gizi Ibu Hamil Serta Pengaruhnya Terhadap Bayi Yang Dilahirka.

Suryawati, Chriswardani.200. Faktor sosial budaya dalam praktik perawatan kehamilan, persalinan, dan pasca persalinan (studi di kecamatan bangsri kabupaten jepara). Jurnal promosi kesehatan Indonesia vol.2/no.1

Maharlouei, N. (2016). The Importance of Social Support During Pregnancy. Women's Health Bull, 3(1): e34991. doi: 10.17795/whb34991

O'Neil, D. (2006). Processes of Change. http:// www. anthro.palomar.edu 
